\title{
THE INFLUENCE OF EXERCISE TRAINING ON QT DISPERSION AND RISK FACTORS FOR CARDIOVASCULAR DISEASES IN PATIENTS AFTER CORONARY ARTERY BYPASS GRAFT SURGERY
}

\author{
Viktor Stoičkov ${ }^{1,2}$, Sandra Šarić ${ }^{1}$, Stanoje Andonovi, Svetlana Kostić1, \\ Milan Lović ${ }^{1}$, Marija Sekulović ${ }^{1}$
}

\begin{abstract}
The aim of this study was to determine the impact of exercise training on QT dispersion and risk factors for cardiovascular disease in patients after coronary artery bypass graft surgery (CABG).

143 patients after CABG, in a sinus rhythm, without atrioventricular or branch blocks, average age 57.5 years, were involved in the study. Patients were randomly divided into the exercise training group (TG: 107 patients) and non-training group (NTG: 36 patients). In addition to clinical examination and laboratory analysis, all the subjects had standard ECGs out of which, QTd was calculated and QT dispersion (QTdc) was corrected. The patients performed the exercise test according to Bruce's protocol, after that the participants of the training group were involved in the exercise training. According to the results of the exercise test, the TG of patients was subjected to a certain degree of physical activity (gymnastic exercises, using the bicycle ergometer and walking). During the follow-up period, medication therapy was not changed. After the observed follow-up period of 21 days, the standard ECG and the exercise test were performed, once again.

In TG of patients, after treatment with exercise training, there was a significant reduction in QTd and QTDC ( $p<0.005$ for both parameters). In TG of patients, after 3 weeks, there was a significant reduction in systolic and diastolic blood pressure, heart rate, double product, total and LDL cholesterol ( $p<0.001$ for all parameters). TG of patients, who were on the second exercise test, achieved significantly longer time, while the non-training group showed no significant changes.

The study showed that exercise training has favourable effects on QT dispersion in patients after CABG. Exercise training led to significant reduction in blood pressure, heart rate, double product, cholesterol, as well as significantly improved physical exercise capacity, which has a beneficial effect on the prognosis in these patients.
\end{abstract}

Acta Medica Medianae 2018;57(4):29-35.

Key words: exercise training, coronary artery bypass graft surgery, QT dispersion, risk factors for cardiovascular disease

${ }^{1}$ Institute for Treatment and Rehabilitation "Niška Banja", Niš, Serbia

${ }^{2}$ University of Niš, Faculty of Medicine, Niš, Serbia

Contact: Viktor Stoičkov

Blvd Nemanjića 34A/8, 18000 Niš, Serbia

E-mail: viktorstoickov67@gmail.com

\section{Introduction}

Patients after coronary artery bypass graft surgery (CABG) are at risk of new cardiovascular and arrhythmic events, cardiac death and sudden cardiac death (1). After CABG, patients have a significant reduction in fitness, caused by myocardial damage and long bedding. As a result of prolonged bedding and long physical inactivity, the weakness of skeletal muscle, damage to peripheral circulation, and dysfunction of autonomic nervous system occur. A significant reduction in fitness is clinically manifested by a marked reduction in tolerance to physical effort, the presence of postural hypotension, tachycardia in rest, and mental disorders, most often in the form of depression or anxiety. The degree of reduction of fitness depends mostly on the length of the stay in the bed and the degree of damage to the left ventricular function. Decreased tolerance to effort is due to reduced left ventricular function and decreased skeletal muscle strength, due to decreased perfusion of skeletal muscle and increased peripheral resistance. Tachycardia in rest and disproportionate increa- 
se in the heart rate with less effort is due to the dysfunction of the autonomic nervous system, reduced parasympathetic tone and increased sympathetic tone (2).

After CABG, good control of the risk factors of coronary disease is necessary for the purpose of secondary prevention of coronary disease. After CABG in patients who did not have physical activity, about $15 \%$ of restenosis were recorded in a year, and $88 \%$ of patients experienced adverse cardiovascular events: myocardial infarction, stroke, revascularization procedures and hospitalization due to angina pectoris (3).

Arterial hypertension is a risk factor for myocardial infarction, stroke and myocardial left ventricular hypertrophy, and is a serious threat to the development of heart failure and cardiac death. Arterial hypertension is the cause of $2 / 3$ of stroke and $1 / 2$ of ischemic heart disease. Thus, arterial hypertension remains the leading cause of mortality and represents a major health problem, as well (4). Poor nutrition and physical inactivity are in favour of atherosclerosis (5). It has been noted that in individuals with low physical activity, intima of carotid arteries is intensified, while significant changes in individuals with higher physical activity do not appear (6).

The rate of development of atherosclerosis under the influence of risk factors for cardiovascular disease depends on whether one or more risk factors, values of certain risk factors are present as well as the length of its duration. In addition to physical training, reduction of LDL cholesterol is easily achieved by statins and they should be administered immediately and intensively at high doses (7-11).

QT dispersion (QTd) represents the heterogeneity in the repolarization of the ventricular myocardium and the marker is ischemia and electrical instability of the myocardium, reflecting the increased tendency towards ventricular arrhythmias. Several studies have shown that QTd is a significant prognostic marker for arrhythmic events, cardiac mortality and sudden cardiac death in coronary patients (1217).

Considering the fact that QT dispersion is a significant prognostic marker in coronary patients and that patients after CABG are at risk of new cardiovascular events, the aim of this study is to determine the impact of exercise training on QT dispersion and risk factors for cardiovascular disease in patients after CABG.

\section{Material and methods}

The research was carried out at the Institute for Treatment and Rehabilitation Niška Banja, Niš.

One hundred forty three patients after CABG, in a sinus rhythm, without atrioventricular or branch blocks, the average age 57.5 years, 38 women and 109 men, were involved in the study. Patients were randomly divided into the exercise training group (107 patients) and non-training group (36 patients). Patients were of similar age and baseline stress test duration. Patients were included in the study within 3 months after CABG.
In addition to the clinical examination and laboratory analysis, all the subjects had standard ECGs out of which QTd was calculated and corrected QT dispersion (QTdc) as well. The patients were subjected to the exercise test, after that the participants of the training group were involved in the exercise training.

According to the results of the exercise test, the training group patients were subjected to the degree of physical activity (gymnastic exercises, using the bicycle ergometer and walking). During the follow-up period, medication therapy was not changed. After the observed follow-up period of 21 days, the standard ECG and the exercise test were performed once again.

QT interval was determined according to ECG, from the starting point of the $\mathrm{Q}$ or $\mathrm{R}$ peak to the end of the $T$ wave-where the down-slope of the $T$ wave merged with the isoelectric line. The QT interval was determined in each offset from three consecutive sinus cycles as a mean value. The values of QT intervals were corrected for the frequency of heart rate according to Bazett's formula (18). QT dispersion was determined as the difference derived from the maximal and minimal value of QT interval found in any of the 12 offsets. Out of the corrected value of QT interval, where the minimal value was subtracted from the maximum value found in any of the ECG offsets, the corrected value for QT dispersion (QT dc) was obtained.

All participants in the study were subjected to treadmill exercise test according to Bruce's protocol (19). The criteria for discontinuation of the test were the following: 1) sub-maximal heart frequency (defined as $85 \%$ of heart frequency); 2) depression of ST segment greater than $2 \mathrm{~mm}$; 3) reduction of systolic blood pressure for 10 or more $\mathrm{mmHg}$ during the exercise; 4) increased values of blood pressure greater than $240 / 120 \mathrm{mmHg}$; 5) occurrence of significant symptoms or arrhythmias. ECG criteria for a positive exercise test were the following: the presence of the horizontal or downstream ST depression $\geq 1 \mathrm{~mm}$ than isoelectric line lasting longer than 0.08 seconds in three consecutive cycles; ischemic elevation of ST segment $\geq 1 \mathrm{~mm}$ in offsets without $\mathrm{Q}$ peak.

\section{Statistical Analyses}

Characteristics of study and control group were expressed as mean \pm SD (continuous variables), with number and \% in brackets (categorical variables). We compared clinical and biochemical data of patients and the control group using Student t-test for normally distributed data (expressed as mean \pm SD). All analyses were performed with SPSS statistical analysis software, version 10.0 (SPSS, Chicago, IL, United States) at the significance level set at $p<0.05$. 


\section{Results}

In patients after CABG, the baseline values of the monitored parameters did not differ between the two groups of subjects, Table 1.

In the training group of patients, after treatment with exercise training, there was a significant reduction in QTd and QTDC parameters, systolic and diastolic blood pressure, heart rate, double product, total and LDL cholesterol, Table 2 . The training group of patients who were on the second exercise test achieved significantly longer time, Table 2.

In the non - training group of patients, after the 21 - day follow - up period, there were no significant changes in the monitored parameters, Table 3.

Table 1. Baseline values of monitored parameters in examined groups of patients, compared with Student $t$-test

\begin{tabular}{|c|c|c|c|}
\hline Monitored parameters & Training group of patients & $\begin{array}{c}\text { Non - training group } \\
\text { of patients }\end{array}$ & $P$ \\
\hline $\bar{N}$ & 107 & 36 & - \\
\hline QTd (ms) & $48.2 \pm 15.9$ & $47.8 \pm 14.5$ & NS \\
\hline QTdc (ms) & $50.5 \pm 18.2$ & $50.2 \pm 16.5$ & NS \\
\hline Systolic blood pressure $(\mathrm{mmHg})$ & $138.7 \pm 13.9$ & $137.6 \pm 14.4$ & NS \\
\hline Diastolic blood pressure $(\mathrm{mmHg})$ & $88.5 \pm 8.4$ & $87.9 \pm 9.3$ & NS \\
\hline Heart rate (beats/min) & $77.3 \pm 7.8$ & $76.9 \pm 6.9$ & NS \\
\hline Double product (beat/min $\times \mathrm{mmHg}$ ) & $11546.7 \pm 912.5$ & $11498.8 \pm 1047.3$ & NS \\
\hline Total cholesterol (mmol/L) & $5.1 \pm 1.6$ & $5.2 \pm 2.1$ & NS \\
\hline LDL cholesterol (mmol/L) & $3.1 \pm 0.9$ & $3.1 \pm 1.1$ & NS \\
\hline Glycemia (mmol/L) & $5.3 \pm 2.1$ & $5.1 \pm 1.9$ & NS \\
\hline Time achieved on the exercise test (min) & $5.3 \pm 1.4$ & $5.5 \pm 1.4$ & NS \\
\hline
\end{tabular}

Data are expressed as X \pm SD-compared with Student-t test.

QTd: QT dispersion; QTdc: corrected QT dispersion

Table 2. Comparison of monitored parameters in the training group of patients before and after treatment with exercise training, compared with Student t-test

\begin{tabular}{|c|c|c|c|}
\hline Monitored parameters & Before exercise training & After exercise training & $P$ \\
\hline $\mathrm{N}$ & 107 & 107 & - \\
\hline QTd (ms) & $48.2 \pm 15.9$ & $42.1 \pm 14.2$ & 0.005 \\
\hline QTdc (ms) & $50.5 \pm 18.2$ & $43.6 \pm 15.7$ & 0.005 \\
\hline Systolic blood pressure $(\mathrm{mmHg})$ & $138.7 \pm 13.9$ & $129.2 \pm 9.3$ & 0.001 \\
\hline Diastolic blood pressure $(\mathrm{mmHg})$ & $88.5 \pm 8.4$ & $83.6 \pm 5.9$ & 0.001 \\
\hline Heart rate (beats/min) & $77.3 \pm 7.8$ & $68.8 \pm 6.9$ & 0.001 \\
\hline Double product (beat/min $\times \mathrm{mmHg}$ ) & $11546.7 \pm 912.5$ & $10227.6 \pm 628.4$ & 0.001 \\
\hline Total cholesterol (mmol/L) & $5.1 \pm 1.6$ & $4.7 \pm 1.2$ & 0.025 \\
\hline LDL cholesterol (mmol/L) & $3.1 \pm 0.9$ & $2.9 \pm 0.6$ & 0.05 \\
\hline Glycemia (mmol/L) & $5.3 \pm 2.1$ & $4.6 \pm 1.2$ & 0.005 \\
\hline Time achieved on the exercise test (min) & $5.3 \pm 1.4$ & $8.2 \pm 1.9$ & 0.001 \\
\hline
\end{tabular}

Data are expressed as X \pm SD-compared with Student-t test.

QTd: QT dispersion; QTdc: corrected QT dispersion 
Table 3. Comparison of monitored parameters in the non - training group of patients before and after follow up period (three weeks), compared with Student t-test

\begin{tabular}{|c|c|c|c|}
\hline Monitored parameters & Before exercise training & After exercise training & $\mathrm{P}$ \\
\hline $\mathrm{N}$ & 36 & 36 & - \\
\hline QTd (ms) & $47.8 \pm 14.5$ & $47.6 \pm 13.9$ & NS \\
\hline QTdc (ms) & $50.2 \pm 16.5$ & $49.8 \pm 15.9$ & NS \\
\hline Systolic blood pressure $(\mathrm{mmHg})$ & $137.6 \pm 14.4$ & $134.2 \pm 13.9$ & NS \\
\hline Diastolic blood pressure $(\mathrm{mmHg})$ & $87.9 \pm 9.3$ & $86.2 \pm 8.8$ & NS \\
\hline Heart rate (beats/min) & $76.9 \pm 6.9$ & $74.2 \pm 7.8$ & NS \\
\hline Double product (beat/min $x \mathrm{mmHg}$ ) & $11498.8 \pm 1047.3$ & $11258.4 \pm 1273.5$ & NS \\
\hline Total cholesterol (mmol/L) & $5.2 \pm 2.1$ & $5.1 \pm 2.3$ & NS \\
\hline LDL cholesterol (mmol/L) & $3.1 \pm 1.1$ & $3.1 \pm 1.2$ & NS \\
\hline Glycemia (mmol/L) & $5.1 \pm 1.9$ & $5.0 \pm 2.1$ & NS \\
\hline Time achieved on the exercise test (min) & $5.5 \pm 1.4$ & $5.9 \pm 1.7$ & NS \\
\hline
\end{tabular}

Data are expressed as X \pm SD-compared with Student-t test.

QTd: QT dispersion; QTdc: corrected QT dispersion

\section{Discussion}

In our patients after CABG, a significant reduction in blood pressure was found after treatment with exercise training. Reducing the high blood pressure leads to a significant reduction in the risk of stroke, heart and renal failure, aortic dissection, adverse cardiac events and total mortality rate, as well $(5,7)$. Reducing high blood pressure due to physical training in our patients after CABG contributes to a significant reduction in the risk of new cardiovascular events. Long-term resistant training contributes to the maintenance of the normal structure and function of the heart, maintains the elasticity of the aorta and maintains lower blood pressure, too (20). Physical training in cardiovascular patients improves survival and reduces hospitalization $(7,21)$.

After a physical exercise was performed in our patients after CABG, a significant reduction in total and LDL cholesterol was found. In coronary patients, lipid reduction due to statin therapy leads to a significant increase in survival and decreases cardiac mortality, as well. In patients at very high risk, LDL cholesterol reduction is required below $1.8 \mathrm{mmol} / \mathrm{L}$ $(8,11)$. Reducing total and LDL cholesterol in our patients after CABG indicates the significant importance of exercise training. The rate of development of atherosclerosis under the influence of risk factors for cardiovascular disease depends on whether one or more risk factors are present as well as the length of its duration. Comparing patients receiving a high dose of statins with those receiving a regular dose after CABG, the medium - and long-term efficacy of a high dose showed significant reduction in LDL-C, lower occurrence of adverse cardiac events, and reduction in graft restenosis (9).

After treatment with exercise training, in our training group of patients, apart from significantly reduced heart rate, blood pressure and cholesterol, a significant reduction in QTd and QTdc was recorded. The most important factor responsible for reducing QTd parameters is the improvement of the function of the autonomic nervous system, as a significant reduction in the heart rate has been found. It is probable that an improvement in collateral myocardial circulation contributed to the reduction of QTd parameters, as many studies have shown that ischemia increases QTd $(15,22,23)$.

The function of the autonomic nervous system affects the values of QTd parameters, as circadian variation is observed in healthy individuals. These variations are probably the result of the change in the tone of the autonomic nervous system. There was a significant increase in QTd in the early morning hours. This morning rise in QTd values coincides with the time when there is increased myocardial vulnerability to ventricular tachycardia and fibrillation as well as sudden cardiac death. The increased QTd value is a significant marker for the development of malignant ventricular arrhythmias when sympathetic tone is increased. However, the same degree of QTd increase will not indicate the same degree of risk for malignant ventricular arrhythmias when the tone of the vagus is increased (24). Administration of insulin, which leads to hypoglycaemia and increased sympathetic tone, causes an increase in QTd values (25). It has been shown that administration of noradrenaline causes a significant increase in QTd values (26). Considering that a significant reduction in blood pressure and heart rate has occurred in our patients after a treatment with exercise training, we can conclude that there has been an improvement in the function of the autonomic nervous system, reducing sympathetic tone and increasing the tone of the vagus.

In our patients after $C A B G$, after the treatment with exercise training, a significant increase in physical exercise capacity was observed. Training 
group of patients on the second exercise test achieved a significantly longer time and higher load level. Also, training group of patients experienced a significant reduction in double product. Exercise training leads to an extension period of time for the appearance of angina pain at the time of loading or even eliminates it, since it increases VO max by reducing the heart rate and systolic blood pressure at a certain load. This reduction in the double product leads to the reduction of myocardial oxygen uptake, which prolongs the time until anginosis appears (3).

\section{Conclusion}

The study showed that exercise training has favourable effects on QT dispersion in patients after CABG. In patients after $C A B G$, exercise training led to a significant reduction in blood pressure, heart rate, double product, and cholesterol, and significantly improved physical exercise capacity, which has a beneficial effect on the prognosis in these patients.
1. Kulik A. Secondary prevention after coronary artery bypass graft surgery: a primer. Curr Opin Cardiol 2016; 31(6):635-43. [CrossRef] [PubMed]

2. Dennis C. Rehabilitation of patients with coronary artery disease. In: Braunwald E, editors. Heart disease. Philadelphia: W.B. Saunders Company; 1997. p. 1392-401.

3. Thompson PD. Exercise based, comprehensive cardiac rehabilitation. In: Mann $D$, Zipes DP, Libby $P$, Bonow RO, editors. Heart Disease. Philadelphia: Saunders Elsevier; 2015. p. 1015-20.

4. Victor RG. Systemic hypertension: Mechanisms and diagnosis. In: Mann D, Zipes DP, Libby P, Bonow RO, editors. Heart Disease. Philadelphia: Saunders Elsevier; 2015. p. 1934-51.

5. Victor RG, Libby P. Systemic hypertension: Management. In: Mann D, Zipes DP, Libby $\mathrm{P}$, Bonow RO, editors. Heart Disease. Philadelphia: Saunders Elsevier; 2015. p. 1953-75.

6. Kozakova M, Palombo C, Morizzo C, Nolan JJ, Konrad $\mathrm{T}$, Balkau B, et al. Effect of sedentary behaviour and vigorous physical activity on segment-specific carotid wall thickness and its progression in a healthy population. Eur Heart J 2010; 31:1511-9. [CrossRef] [PubMed]

7. Piepoli MF, Hoes AW, Agewall S, Albus C, Brotons C, Catapano AL, et al. 2016 European Guidelines on cardiovascular disease prevention in clinical practice: The Sixth Joint Task Force of the European Society of
Cardiology and Other Societies on Cardiovascular Disease Prevention in Clinical Practice (constituted by representatives of 10 societies and by invited experts) Developed with the special contribution of the European Association for Cardiovascular Prevention \&amp; Rehabilitation (EACPR). Eur Heart J 2016; 37:231581. [CrossRef] [PubMed]

8. Catapano AL, Graham I, De Backer G, Wiklund O, Chapman MJ, Drexel H, et al. 2016 ESC/EAS Guidelines for the Management of Dyslipidaemias. Eur Heart J 2016; 37(39):2999-3058.

[CrossRef] [PubMed]

9. Bin C, Junsheng M, Jianqun Z, Ping B. Meta-Analysis of Medium and Long-Term Efficacy of Loading Statins after Coronary Artery Bypass Grafting. Ann Thorac Surg 2016; 101:990-5. [CrossRef] [PubMed]

10. Braunwald E. Reduction of LDL-cholesterol: important at all ages. Eur Heart J 2016; 37:1982-4. [CrossRef] [PubMed]

11. Morrow DA, Boden WE: Stable ischemic heart disease. In: Mann D, Zipes DP, Libby P, Bonow RO, editors. Heart Disease. Philadelphia: Saunders Elsevier; 2015. p. $1182-227$

12. Okin PM, Devereux RB, Fabsitz RR, Lee ET, Galloway JM, Howard BV. Principal component analysis of the T wave and prediction of cardiovascular mortality in American Indians: the Strong Heart Study. Circulation 2002; 105:714-9. [CrossRef] [PubMed] 
13. Padmanabhan S, Silvet H, Amin J, Pai RG. Prognostic value of QT interval and QT dispersion in patients with left ventricular systolic dysfunction: Results from a cohort of 2265 patients with an ejection fraction of $</=40 \%$. Am Heart J 2003; 145:132-8. [CrossRef] [PubMed]

14. Sheehan J, Perry IJ, Reilly M, Salim A, Collins M, Twomey EM, et al. QT dispersion, QT maximum and risk of cardiac death in the Caerphilly Heart Study. Eur J Cardiovasc Prev Rehabil 2004; 11:63-8. [CrossRef] [PubMed]

15. Mirbolouk F, Arami S, Salari A, Shad B, Kazemnejad E, Moladoust H. Corrected QT-interval and dispersion after revascularization by percutaneous coronary intervention and coronary artery bypass graft surgery in chronic ischemia. J Invasive Cardiol 2014; 26(9): 44450. [PubMed]

16. Scott PA, Rosengarten JA, Shahed A, Yue AM, Murday DC, Roberts PR, et al. The relationship between left ventricular scar and ventricular repolarization in patients with coronary artery disease: insights from late gadolinium enhancement magnetic resonance imaging. Europace 2013; 15(6):899-906. [CrossRef] [PubMed]

17. Piranfar MA. The relationship between QT dispersion and ischemic injuries in myocardial isotope scan. Acta Med Iran 2014; 52(5):345-51. [PubMed]

18. Bazett HC. An analysis of the time-relations of electrocardiograms. Heart 1920; 7:353-70.

19. Bruce RA, Fisher LD, Cooper MN, Gey GO. Separation of effects of cardiovascular disease and age on ventricular function with maximal exercise. Am J Cardiol 1974; 34:757-63. [CrossRef]
20. Morra EA, Zaniqueli D, Rodriguez S, El-Aouar LM, Lunz W, Mill JG, et al. Long-term intensive resistance training in man is associated with preserved cardiac structure/function, decreased aortic stiffness and lover central augmentation pressure. J Hypertens 2014; 32(2):286-93. [CrossRef] [PubMed]

21. Martin BJ, Hauer T, Arena R, Austford LD, Galbraith $P D$, Lewin AM, et al. Cardiac rehabilitation attendance and outcomes in coronary artery disease patients. Circulation 2012; 126(6):677-87.

[CrossRef] [PubMed]

22. Stankovic I, Putnikovic B, Janicijevic A, Jankovic M, Cvjetan R, Pavlovic $S$, et al. Myocardial mechanical and QTc dispersion for the detection of significant coronary artery disease. Eur Heart J Cardiovasc Imaging 2015; 16(9):1015-22. [CrossRef] [PubMed]

23. Zhang $F$, Zhang $X$, Zhang $X$, Chen B, Liu Y, Yue WW, et al. Coronary Revascularization Improves QT Dispersion in Patients with Chronic Coronary Artery Total Occlusion. Cell Biochem Biophys 2015; 72:127-30. [CrossRef] [PubMed]

24. Molnar J, Rosental JE, Weiss JS, Somberg JC. QT interval dispersion in healthy subjects and survivors of sudden cardiac death: Circadian variation in a twenty four hour assessment. Am J Cardiol 1997; 79(9): 1190-3. [CrossRef] [PubMed]

25. Robinson RT, Harris ND, Ireland RH, Lee S, Newman C, Heller SR. Mechanisms of abnormal cardiac repolarization during insulin-induced hypoglycemia. Diabetes 2003;52:1469-74. [CrossRef] [PubMed]

26. Sun ZH, Swan H, Viitasalo M, Toivonen L. Effects of epinephrine and phenylephrine on QT interval dispersion in congenital long QT syndrome. J Am Coll Cardiol 1998; 31:1400-5. [CrossRef] [PubMed] 


\title{
UTICAJ FIZIČKOG TRENINGA NA QT DISPERZIJU I FAKTORE RIZIKA ZA KARDIOVASKULARNE BOLESTI KOD BOLESNIKA NAKON HIRURŠKE REVASKULARIZACIJE MIOKARDA
}

\author{
Viktor Stoičkov ${ }^{1,2}$, Sandra Šarić ${ }^{1}$, Stanoje Andonov ${ }^{1}$, Svetlana Kostić1, \\ Milan Lović ${ }^{1}$, Marija Sekulović ${ }^{1}$
}

${ }^{1}$ Institut za lečenje i rehabilitaciju "Niška Banja", Niš, Srbija

2Univerzitet u Nišu, Medicinski fakultet, Niš, Srbija

Kontakt: Viktor Stoičkov

Bulevar Nemanjića 34A/8, 18000 Niš, Srbija

E-mail: viktorstoickov67@gmail.com

Cilj rada bio je da se ispita uticaj fizičkog treninga na QT disperziju i faktore rizika za kardiovaskularne bolesti kod bolesnika nakon hirurške revaskularizacije miokarda (CABG).

Studijom je obuhvaćeno 143 bolesnika nakon CABG, u sinusnom ritmu, bez AV blokova i blokova grana, prosečne starosti 57,5 godina. Bolesnici su podeljeni u grupu sa fizičkim treningom (TG: 107 bolesnika) i ne-trening grupu (NTG: 36 bolesnika). Bolesnici su imali sličnu starost i trajanje testa opterećenja. Svim ispitanicima je pored kliničkog pregleda i laboratorijskih analiza urađen standardni EKG iz kojeg je izračunavana QTd i korigovana QT disperzija (QTdc). Bolesnicima je takođe urađen test fizičkim opterećenjem na pokretnoj traci po Bruceovom protokolu, nakon čega su ispitanici TG uključeni u tretman fizičkim treningom. $\mathrm{Na}$ osnovu rezultata testa opterećenja, ispitanicima TG je određivan stepen fizičke aktivnosti (gimnastičke vežbe, terenske staze, vožnja na ergobiciklu). Tokom perioda praćenja ispitanicima nije menjana medikamentna terapija. Nakon sprovedenog perioda praćenja, koji je trajao 21 dan, bolesnicima je ponovo rađen standardni EKG i test fizičkim opterećenjem.

Kod ispitanika TG, nakon sprovedenog tretmana fizičkim treningom, došlo je do značajnog smanjenja vrednosti parametara QTd i QTdc ( $p<0,005$ za oba parametra) i do značajnog smanjenja sistolnog i dijastolnog arterijskog pritiska, frekvencije srčanog rada, dvojnog proizvoda, ukupnog i LDL holesterola ( $p<0,001$ za sve parametre). Ispitanici TG na drugom testu opterećenja postigli su značajno duže vreme $(p<0,001)$. Kod ispitanika NTG parametri se nisu značajno promenili nakon perioda praćenja.

Studija je pokazala da je kod bolesnika nakon CABG, fizički trening izazvao značajno smanjenje parametara QTd, arterijskog pritiska, frekvencije srčanog rada, dvojnog proizvoda i holesterola, a značajno je poboljšan funkcionalni radni kapacitet, što povoljno utiče na prognozu bolesti.

Acta Medica Medianae 2018;57(4):29-35.

Ključne reči: fizički trening, hirurška revaskularizacija miokarda, QT disperzija, faktori rizika za kardiovaskularne bolesti 